\title{
EFFECT OF IRRIGATION AND POLYACRYLAMIDE ON THE PRODUCTION OF GLADIOLUS PLANTS IN SANDY SOILS
}

(Received: 9.7.2014)

\author{
By \\ N. A. El-Shanhorey and R. A. Soffar* \\ Department of Botanical Garden Research and * Department of Ornamental Plants Research - \\ Antonuades, Horticultural Research Institute, Agricultural Research Center, Alexandria, Egypt
}

\begin{abstract}
This investigation was carried out during 2012/2013 and 2013/2014 seasons on Gladiolus hybrida cv. "White Prosperity" grown in plastic pots of $20 \mathrm{~cm}$ diameter at Antoniades Research Branch, Horticulture Institute, Ministry of Agriculture, Alexandria, Egypt. The study was a trial to investigate the effect of different levels of irrigation $(20 \%, 40 \%, 60 \%, 80 \%$ and $100 \%$ of the field capacity) and different ratios of polyacrylamide as a synthetic soil conditioner $(0.0,0.1,0.2$ and 0.4 $\%)$ and their combinations (20 treatments) on the vegetative growth, flowering characteristics, corms production and some chemical constituents of gladiolus plants grown in sandy soils.

Results revealed that the irrigation level was more effective than polyacrylamide ratios on all the studied characteristics of gladiolus plants. Also, using the highest level of the available moisture (100 $\%$ of field capacity) combined with polyacrylamide at $0.2 \%$ gave the highest significant values on the plant height, leaf number, floret number, rachis length, corm diameter, cormlet number per plant, carbohydrate content of the new corms and the shortest period needed from planting to showing colour. The maximum values of the leaf area, leaf fresh and dry weights, flowering duration, florets dry weight, leaf chlorophyll and the minimum leaf proline contents were found by the highest irrigation level (100\% of field capacity) alone.

Generally, the results obtained suggest that irrigating the cultivated gladiolus in the sandy soil daily with using irrigation level not less than $80 \%$ of field capacity combined with polyacrylamide at the rate of $0.2 \%$ provided improvements in the vegetative growth, flowering characteristics, corm production and the quantity of some products of gladiolus plants grown in sandy soil.
\end{abstract}

Key words: Gladiolus hybrida - irrigation - polyacrylamide.

\section{INTRODUCTION}

Gladiolus is one of the most important cut flower crops in the floricultural industry and it is the most widely grown outdoor cut flower in Egypt. The name gladiolus is derived from the Latin word "Gladius" meaning sword (Clarence, 1945).

Gladiolus is represented by 180 species (Lewis et al., 1972). The species of the genus gladiolus are chiefly found in south and central Africa and around the Mediterranean area. The species of gladiolus belong to Iridaceae family.

Gladiolus flowers can be all colours, except true blue, although some of the violet shades appear to be very near to blue in subdued light.

The modern gladiolus cultivars offer a diversity of colours, shapes and sizes. Therefore, they can be used as landscape plants in the home garden as specimens for exhibition, and as cut flowers.

Water is becoming an economical scarce resource in many areas of the world, especially in the arid and semi-arid regions. So, increasing water use efficiency and saving irrigation water are important tasks. Nevertheless, even under adequate soil moisture, water stress might develop causing a great variations in most, if not all, the physiological and biochemical processes. Misra and Srivastava (2000) reported that water stress resulted in a significant reduction in chlorophyll content of leaves and in essential oil yield of Mentha arvensis. Mohamed (2002) studying Rosmarinus officinalis and pelargonium graveolens, found that a gradual increase in the fresh and dry weights/plant with increasing irrigation level. The maximum fresh and dry 
weights/plant and per feddan were obtained by drip irrigation at the rate of $8 \mathrm{l} / \mathrm{h}$.

Generally, cultivation on arid sandy soils requires large quantities of water. The low water holding capacity of this soil causes rapid infiltration and deep percolation below the root zone. The uses of gel-forming hydrophilic polymers have been tested for some years to solve such problem. Polyacrylamide (PAM) is a polymer composed of many subunits of acrylamide molecules, which are linked to identical copies of itself to form long chain-link molecules. PAM is synthesized from natural gas and was originally developed in the 1940s and 1950s for use as a soil conditioner. There is in fact thousands kinds of PAM which vary with the length and ionicity of the polymer chain. Gel-forming or superabsorbant polymers are soil conditioners developed to aid plant

\section{MATERIALS AND METHODS}

The present study was carried-out during the two successive seasons of (2012/2013) and (2013/2014) at Antoniades Research Branch, Horticulture Research Institute, A.R.C. Alexandria, Egypt.

Corms of Gladiolus hybrida cultivar "White Prosperity" were chosen for their popularity and adaptability to the Egyptian environment and for the possibility to export. Corms were imported from Holland for both seasons of the study. The circumferences of the used corms ranged between $8-10 \mathrm{~cm}$. Corms were planted in plastic pots of $20 \mathrm{~cm}$ at a depth of $5 \mathrm{~cm}$ on October $9^{\text {th }}$, 2012 and October $7^{\text {th }}, 2013$ for the first and second seasons, respectively. The pots were filled with a sandy soil (6 Kg per pot). The analysis of the used sandy soil as described by Jackson (1958) in Table (1).

Table (1): Chemical analysis of the used sandy soil for the two successive seasons (2012/2013) and (2013/2014).

\begin{tabular}{|c|c|c|c|c|c|c|c|c|c|}
\hline Season & $\mathbf{p H}$ & \multirow{2}{*}{$\begin{array}{c}\text { EC } \\
(\mathbf{m m o h s} / \mathbf{c m})\end{array}$} & \multicolumn{3}{|c|}{ Soluble cations (mg/l) } & \multicolumn{3}{c|}{ Soluble anions (mg/l) } \\
\cline { 4 - 10 } & & $\mathbf{C a}^{++}$ & $\mathbf{M g}^{++}$ & $\mathbf{N a}^{+}$ & $\mathbf{K}^{+}$ & $\mathbf{H C O}_{\mathbf{3}}^{-}$ & $\mathbf{C l}^{-}$ & $\mathbf{S O}_{\mathbf{2}}^{--}$ \\
\hline $\mathbf{2 0 1 2 / 2 0 1 3}$ & 8.10 & 1.30 & 3.0 & 4.4 & 6.5 & 1.1 & 3.5 & 6.5 & 2.5 \\
\hline $\mathbf{2 0 1 3 / 2 0 1 4}$ & 8.02 & 1.06 & 3.4 & 2.8 & 6.0 & 0.6 & 3.0 & 6.0 & 2.0 \\
\hline
\end{tabular}

establishment in drought prone soils. The polymers commonly available come mainly from three chemical families, Johnson (1984). Mostafa (2002) reported that adding polyacrylamide at $0.1-0.2 \%$ to the sandy soil under the irrigation frequencies regime of once/ 2 day enhanced most of plant growth indices of Dendranthema grandiflorum cv. Hawaii. Sivapalan (2006) demonstrated that the excess amount of water stored in the soil by polyacrylamide was available to plants and resulted in higher water use. Consequently, there were 12 and 18 fold increases in water use efficiency of soybean plants grown in soils treated with 0.03 and $0.07 \%$ polyacrylamide, respectively.

The objective of this investigation was to study the effects of using different percentages of field capacity (irrigation levels), ratios of polyacrylamide and their combinations on the vegetative growth, flowering characteristics, corms and cormlets production and some chemical analysis of Gladiolus hybrida cv. "White Prosperity" grown in sandy soils under the prevailing conditions of Alexandria, Egypt.
Five irrigation levels were used to keep the soil moisture at the field capacity of the used sandy soil at 20\%, 40\%, 60\%, $80 \%$ and $100 \%$. The reduction in the moisture level of each treatment was determined daily using Moisture Tester Model KS-DI (Gypsum Block) during the growing seasons.

The amounts of water for the different treatments were added daily to each pot to keep the soil moisture of each treatment at the corresponding percentage using tap water as a source of irrigation. At the end of the experiment the total amount of irrigation water used for each treatment was calculated and presented in Table (2).

The "Flowrowger" is a commercial name of a synthetic polymer with white granular substrate that contains $97 \%$ polyacrylamide (PAM) and has water retention capacity of 600 times on its weight basis, was used as a source of polyacrylamide (PAM). Four concentrations from this polymer were used, i.e. 0.0 (control), $0.1,0.2$ and $0.4 \%$ on the basis of soil weight (w/w). Each level from this polymer was completely mixed with the used soil directly 
Table (2): Total amount of the water used for each plant (1/pot) in each treatment during the growing of the two seasons (2012/2013) and (2013/2014).

\begin{tabular}{|l|c|c|c|c|c|c|c|c|c|c|}
\hline \multirow{2}{*}{ Field Capacity } & \multicolumn{4}{|c|}{ First season (2012/2013) } & \multicolumn{4}{c|}{ Second season (2013/2014) } \\
\cline { 2 - 11 } & \multicolumn{4}{|c|}{ Polyacrylamide concentration } & \multicolumn{3}{c|}{ Polyacrylamide concentration } \\
\cline { 2 - 11 } & $\mathbf{0 . 0 \%}$ & $\mathbf{0 . 1 \%}$ & $\mathbf{0 . 2 \%}$ & $\mathbf{0 . 4 \%}$ & Mean & $\mathbf{0 . 0 \%}$ & $\mathbf{0 . 1 \%}$ & $\mathbf{0 . 2 \%}$ & $\mathbf{0 . 4 \%}$ & Mean \\
\hline $\mathbf{1 0 0}$ & 63.00 & 62.25 & 61.80 & 61.00 & $\mathbf{6 2 . 0 0}$ & 63.80 & 63.00 & 62.65 & 61.85 & $\mathbf{6 2 . 8 2}$ \\
\hline $\mathbf{8 0}$ & 53.00 & 52.25 & 51.80 & 51.00 & $\mathbf{5 2 . 0 0}$ & 53.80 & 53.00 & 52.65 & 51.85 & $\mathbf{5 2 . 8 2}$ \\
\hline $\mathbf{6 0}$ & 43.00 & 42.25 & 41.80 & 41.00 & $\mathbf{4 2 . 0 0}$ & 43.80 & 43.00 & 42.65 & 41.85 & $\mathbf{4 2 . 8 2}$ \\
\hline $\mathbf{4 0}$ & 33.00 & 32.25 & 31.80 & 31.00 & $\mathbf{3 2 . 0 0}$ & 33.80 & 33.00 & 32.65 & 31.85 & $\mathbf{3 2 . 8 2}$ \\
\hline $\mathbf{2 0}$ & 23.00 & 22.25 & 21.80 & 21.00 & $\mathbf{2 2 . 0 0}$ & 23.80 & 23.00 & 22.65 & 21.85 & $\mathbf{2 2 . 8 2}$ \\
\hline
\end{tabular}

before planting, Devitt et al. (1991).

Five levels of field capacity and four concentrations of polyacrylamide were used, 20 treatments for each season. The design was a split plot with three replicates, each replicate contain 3 plants. The main plots were the irrigation levels while the subplots were the concentrations of polyacrylamide. The means of individual factors and their interactions were compared using L.S.D. test at 5\% level of probability, Snedecor and Cochran (1974).

Fertilization of the plants was started three weeks after sprouting of the corms. Two types of compound fertilizers $\left(\mathrm{N}: \mathrm{P}_{2} \mathrm{O}_{5}: \mathrm{K}_{2} \mathrm{O}\right)$ were used for accelerating the vegetative growth and enhanced the quality of the produced flowers and corms. These fertilizers were 19:19:19 for the vegetative growth followed by 12:12:36 for flowering and corm developing (Yadav and Maity, 1989). Each plant under the experiment was fertilized with $16 \mathrm{~g}$. This amount was divided into four equal doses, from each fertilizer type. Each dose was added to the soil surface as a top dressing at biweekly intervals. It was added for the first time after twenty one days of sprouting (November 13, in the first season and November 11, in the second season).

Plants requirement of magnesium $(\mathrm{Mg})$ and iron (Fe) were added as $\mathrm{MgSO}_{4} \cdot \quad 7 \mathrm{H}_{2} \mathrm{O}$ (Magnesium Sulphate $=9.5 \% \mathrm{Mg}$ ) and $\mathrm{Fe}$ EDTA (Disodium $\mathrm{Fe}$ of chelate ethylene diamine tetraacetic acid $=18 \% \mathrm{Fe}$ ), which were sprayed four times at three weekly intervals on the plant foliage until the run -off point at 150 and $75 \mathrm{ppm}$ for $\mathrm{Mg}$ and $\mathrm{Fe}$, respectively ( Matt and Muhar, 1990 ). The first dose was sprayed on October 13, 2012 and October 11, 2013 for the first and second seasons, respectively.

The following data were recorded: plant height, leaf number, leaf area, leaf fresh and dry weights per plant, number of days to showing color, floret diameter per spike, flowering duration on the plant, floret number, rachis length, floret dry weight, corm diameter, corm dry weight, number of cormlets per plant, total chlorophyll content according to Moran and Porath (1980), leaf proline content as a water stress indicator according to Bates et al. (1973) and carbohydrate content according to Dubios et al. (1956) of the new corms.

\section{RISULTS AND DISCUSSION \\ 3.1.vegetative $g$ rowth}

Generally, data of the two seasons indicated that the irrigation levels were more effective than that of the polyacrylamide rates on all the studied characteristics of gladiolus plants. This result may be due to the poor ability of sandy soil to hold enough water to supply the gladiolus plants. with their needs of water and essential elements to grow well, thus any application of water led to improving the growth rate of gladiolus plants. The data of the two seasons in Table (3) showed that the tallest plants were obtained by using available moisture at $100 \%$ of field capacity combined with polyacrylamide at $0.2 \% 91.50$ and $92.83 \mathrm{~cm}$ in 2012/2013 and 2013/2014 seasons, respectively, as compared with the other treatments. These results were probably due to the fact that sprouting the gladiolus corms requires a suitable level of available moisture in the medium to encourage the initiation and development of the roots and buds, besides that using the proper concentration of the polyacrylamide led to improve the water holding capacity and reduced the infiltration rate of the sandy soil. Thus the soil can reserve an enough amount of water needed to give the tallest plant. 
Table (3): Means of vegetative growth characteristics of Gladiolus hybrida cv. White Prosperity plants as influenced by field capacity percentage (F.C.), polyacrylamide (PAM) percentage (\%) and their combinations (F.C. $\times$ PAM) in the two seasons of (2012/2013) and (2013/2014).

\begin{tabular}{|c|c|c|c|c|c|c|c|c|c|c|c|}
\hline \multicolumn{2}{|c|}{ Treatments } & \multicolumn{2}{|c|}{$\begin{array}{l}\text { Plant height } \\
\text { (cm) }\end{array}$} & \multicolumn{2}{|c|}{$\begin{array}{c}\text { Leaves } \\
\text { number per } \\
\text { plant }\end{array}$} & \multicolumn{2}{|c|}{$\begin{array}{l}\text { Leaf area } \\
\quad\left(\mathrm{cm}^{2}\right)\end{array}$} & \multicolumn{2}{|c|}{$\begin{array}{c}\text { Leaves fresh } \\
\text { weight per } \\
\text { plant (g) } \\
\end{array}$} & \multicolumn{2}{|c|}{$\begin{array}{c}\text { Leaves dry } \\
\text { weight per } \\
\text { plant }(g)\end{array}$} \\
\hline $\begin{array}{c}\text { Field } \\
\text { capacity } \\
(\%)\end{array}$ & $\begin{array}{c}\text { Polyacrylamide } \\
(\%)\end{array}$ & $\begin{array}{c}2012 \\
/ 2013\end{array}$ & $\begin{array}{l}2013 \\
/ 2014\end{array}$ & $\begin{array}{r}2012 \\
/ 2013\end{array}$ & $\begin{array}{l}2013 \\
/ 2014\end{array}$ & $\begin{array}{r}2012 \\
/ 2013\end{array}$ & $\begin{array}{l}2013 \\
/ 2014\end{array}$ & $\begin{array}{c}2012 \\
/ 2013\end{array}$ & $\begin{array}{r}2013 \\
/ 2014\end{array}$ & $\begin{array}{l}2012 \\
/ 2013\end{array}$ & $\begin{array}{r}2013 \\
/ 2014\end{array}$ \\
\hline \multirow{4}{*}{$20 \%$} & $0.0 \%$ & 74.00 & 75.66 & 6.00 & 6.00 & 305.86 & 311.41 & 24.53 & 24.76 & 4.01 & 3.92 \\
\hline & $0.1 \%$ & 76.50 & 78.16 & 6.00 & 6.00 & 316.27 & 320.14 & 25.43 & 25.87 & 4.16 & 4.10 \\
\hline & $0.2 \%$ & 77.00 & 78.66 & 6.00 & 6.00 & 318.34 & 323.89 & 25.53 & 26.69 & 4.18 & 4.23 \\
\hline & $0.4 \%$ & 72.83 & 74.50 & 6.00 & 6.00 & 301.09 & 307.12 & 24.14 & 24.97 & 3.95 & 3.95 \\
\hline \multicolumn{2}{|l|}{ Mean } & 75.08 & 76.74 & 6.00 & 6.00 & 310.39 & 315.64 & 24.90 & 25.57 & 4.07 & 4.05 \\
\hline \multirow{4}{*}{$40 \%$} & $0.0 \%$ & 75.83 & 77.50 & 6.00 & 6.00 & 313.52 & 317.41 & 25.13 & 25.67 & 4.11 & 4.07 \\
\hline & $0.1 \%$ & 77.16 & 78.33 & 6.33 & 6.33 & 319.02 & 324.16 & 25.74 & 26.59 & 4.21 & 4.22 \\
\hline & $0.2 \%$ & 80.83 & 82.66 & 6.50 & 6.66 & 334.33 & 340.35 & 26.81 & 27.79 & 4.39 & 4.40 \\
\hline & $0.4 \%$ & 81.16 & 82.33 & 6.16 & 6.16 & 335.58 & 331.48 & 26.89 & 26.33 & 4.40 & 4.18 \\
\hline \multicolumn{2}{|l|}{ Mean } & 78.74 & 80.20 & 6.25 & 6.29 & 325.61 & 328.35 & 26.14 & 26.59 & 4.27 & 4.21 \\
\hline \multirow{4}{*}{$60 \%$} & $0.0 \%$ & 77.83 & 79.50 & 6.00 & 6.00 & 321.75 & 327.57 & 25.88 & 26.45 & 4.23 & 4.19 \\
\hline & $0.1 \%$ & 81.16 & 82.00 & 6.33 & 6.50 & 335.61 & 337.59 & 26.89 & 27.59 & 4.40 & 4.37 \\
\hline & $0.2 \%$ & 83.16 & 84.33 & 6.66 & 6.83 & 343.81 & 347.20 & 28.28 & 28.64 & 4.63 & 4.54 \\
\hline & $0.4 \%$ & 80.66 & 82.33 & 6.33 & 6.50 & 333.54 & 333.15 & 26.74 & 27.16 & 4.38 & 4.31 \\
\hline \multicolumn{2}{|l|}{ Mean } & 80.70 & 82.04 & 6.33 & 6.45 & 333.67 & 336.37 & 26.94 & 27.46 & 4.41 & 4.35 \\
\hline \multirow{4}{*}{$80 \%$} & $0.0 \%$ & 82.50 & 83.66 & 6.00 & 6.00 & 340.98 & 344.44 & 37.38 & 34.71 & 6.12 & 5.51 \\
\hline & $0.1 \%$ & 86.50 & 87.83 & 6.66 & 6.66 & 357.61 & 359.96 & 38.75 & 36.34 & 6.34 & 5.77 \\
\hline & $0.2 \%$ & 86.16 & 87.50 & 7.50 & 7.33 & 359.56 & 360.23 & 38.68 & 37.78 & 6.33 & 5.99 \\
\hline & $0.4 \%$ & 82.33 & 83.33 & 7.16 & 7.00 & 340.31 & 340.91 & 37.29 & 35.13 & 6.11 & 5.57 \\
\hline \multicolumn{2}{|l|}{ Mean } & 84.37 & 85.58 & 6.83 & 6.75 & 349.61 & 351.38 & 38.02 & 35.98 & 6.22 & 5.71 \\
\hline \multirow{4}{*}{$100 \%$} & $0.0 \%$ & 89.00 & 90.16 & 6.00 & 6.00 & 369.76 & 370.41 & 40.68 & 41.15 & 6.66 & 6.53 \\
\hline & $0.1 \%$ & 90.50 & 91.50 & 7.33 & 7.33 & 380.86 & 380.05 & 41.86 & 44.11 & 6.85 & 6.94 \\
\hline & $0.2 \%$ & 91.50 & 92.83 & 7.83 & 8.00 & 388.27 & 388.90 & 43.51 & 44.57 & 7.14 & 7.07 \\
\hline & $0.4 \%$ & 87.83 & 88.83 & 7.16 & 7.16 & 364.74 & 365.75 & 40.95 & 41.41 & 6.71 & 6.57 \\
\hline \multicolumn{2}{|l|}{ Mean } & 89.70 & 90.83 & 7.08 & 7.12 & 375.90 & 376.27 & 41.75 & 42.81 & 6.84 & 6.77 \\
\hline \multirow{4}{*}{$\begin{array}{l}\text { Mean } \\
\text { (PAM) }\end{array}$} & $0.0 \%$ & 79.83 & 81.29 & 6.00 & 6.00 & 330.37 & 334.24 & 30.72 & 30.54 & 5.02 & 4.84 \\
\hline & $0.1 \%$ & 82.36 & 83.56 & 6.53 & 6.56 & 341.87 & 344.38 & 31.73 & 32.10 & 5.19 & 5.08 \\
\hline & $0.2 \%$ & 83.73 & 85.19 & 6.89 & 6.96 & 348.86 & 352.11 & 32.56 & 33.09 & 5.33 & 5.24 \\
\hline & $0.4 \%$ & 80.96 & 82.26 & 6.56 & 6.56 & 335.05 & 335.68 & 31.20 & 31.00 & 5.11 & 4.91 \\
\hline \multirow{3}{*}{$\begin{array}{l}\text { L.S.D. } \\
\text { at } 0.05\end{array}$} & F.C. & 0.55 & $\mathbf{0 . 8 3}$ & 0.18 & 0.25 & 1.99 & 2.34 & 0.58 & 2.53 & 0.11 & 0.40 \\
\hline & PAM & 0.41 & 0.49 & 0.16 & 0.14 & 1.82 & 2.74 & 0.22 & 0.26 & 0.03 & 0.04 \\
\hline & F.C. $\times$ PAM & 0.98 & 1.26 & 0.37 & 0.37 & 4.05 & 5.79 & 0.72 & 2.57 & 0.12 & 0.41 \\
\hline
\end{tabular}

Also, the data of the two seasons in Table (3) generally, indicated that using the highest level of the available moisture (100\% of field capacity) combined with polyacrylamide at $0.2 \%$ gave the highest values of the leaves number/plant (7.83 and 8.00), leaf area (388.27 and $\left.388.90 \mathrm{~cm}^{2}\right)$, leaves fresh weight (43.51 and $44.57 \mathrm{gm}$ ) and leaves dry weight (7.14 and 7.07 gm) in first and second seasons, respectively), as compared with the other treatments. These results may be due to the fact that using a suitable level of moisture (100\% of field capacity) at a proper concentration of polyacrylamide activated the root system to grow better and it can absorb the adequate amount of water and fertilizer needed for good plant growth. Besides, increasing the rate of accumulation of the biosynthesates materials in the leaves, thus the leaf number, area, fresh and dry weights could be increased. Similar trend of results was found by Tripepi et al. (1991) with Betula pendula plant, Halepyati et al. (2002) with tuberose and Khattab et al. (2002) with Salvia splendens. Furthermore, in this 
investigation, it is also clear that, in general, using polyacrylamide alone at a concentration of $0.2 \%$ gave significant increases in all studied leaf characters (number, area, fresh and dry weights), compared with the other concentrations.

These results were probably due to the role of polyacrylamide at a suitable concentration on increasing the availability of water and nutrients, thus the rate of food biosynthesis could be increased. Consequently, the plants can produce many large leaves, thus fresh and dry weight increase. Similar trend was found by Al-Harbi et al. (1999) with cucumber and Klock-Moore (2000) with Salvia splendens.

Generally, the average increase of the plant height at $100 \%$ filed capacity and $0.2 \%$ PAM was 91.50 and $92.83 \mathrm{~cm}$ in first and second seasons, respectively. The extent of any fall in the second grade (Class II) of was export (which is how far along spike length was between 90 $120 \mathrm{~cm}$ ), GOEIC (1988). The increase of the plant height at $80 \%$ field capacity and $0.1 \%$ PAM was 86.50 and $87.83 \mathrm{~cm}$ in first and second seasons, respectively. The extent of any fall in the third grade (Class III) for export (which is how far along was spike length was between $80-90 \mathrm{~cm}$ ), GOEIC (1988).

\subsection{Flowering characteristics}

The results of the two seasons in Table (4-a) indicated that the minimum time taken to showing color stage was obtained by using the highest level of the available moisture, which led to decrease the time to 64.00 and 64.33 days under the treatment of $0.2 \%$ PAM in the first and second seasons, respectively, as compared with

Table (4-a): Means of flowering characteristics of Gladiolus hybrida cv. White Prosperity plants as influenced by field capacity percentage (F.C.), polyacrylamide (PAM) percentage (\%) and their combinations (F.C. $\times$ PAM) in the two seasons of (2012/2013) and (2013/2014).

\begin{tabular}{|c|c|c|c|c|c|c|c|}
\hline \multicolumn{2}{|c|}{ Treatments } & \multicolumn{2}{|c|}{$\begin{array}{c}\text { Time } \\
\text { to showing colour } \\
\text { (day) }\end{array}$} & \multicolumn{2}{|c|}{$\begin{array}{c}\text { Floret diameter } \\
\text { per spike }(\mathrm{cm})\end{array}$} & \multicolumn{2}{|c|}{$\begin{array}{c}\text { Flowering duration } \\
\text { (day) }\end{array}$} \\
\hline $\begin{array}{c}\text { Field } \\
\text { capacity }(\%)\end{array}$ & Polyacrylamide (\%) & \begin{tabular}{r|}
2012 \\
$/ 2013$ \\
\end{tabular} & $\begin{array}{r}2013 \\
/ 2014 \\
\end{array}$ & $\begin{array}{r}2012 \\
/ 2013 \\
\end{array}$ & \begin{tabular}{|c|}
2013 \\
$/ 2014$ \\
\end{tabular} & $\begin{array}{r}2012 \\
/ 2013 \\
\end{array}$ & $\begin{array}{c}2013 \\
/ 2014 \\
\end{array}$ \\
\hline \multirow{4}{*}{$20 \%$} & $0.0 \%$ & 88.66 & 89.00 & 6.16 & 6.30 & 11.16 & 10.83 \\
\hline & $0.1 \%$ & 86.66 & 87.00 & 6.37 & 6.54 & 12.33 & 12.83 \\
\hline & $0.2 \%$ & 85.83 & 86.16 & 6.45 & 6.65 & 12.83 & 13.00 \\
\hline & $0.4 \%$ & 88.00 & 88.33 & 6.11 & 6.41 & 11.66 & 11.83 \\
\hline \multicolumn{2}{|l|}{ Mean } & 87.28 & 87.62 & 6.27 & 6.47 & 11.99 & 12.12 \\
\hline \multirow{4}{*}{$40 \%$} & $0.0 \%$ & 83.33 & 83.66 & 6.26 & 6.53 & 11.50 & 11.50 \\
\hline & $0.1 \%$ & 80.83 & 81.16 & 6.52 & 6.78 & 12.50 & 12.83 \\
\hline & $0.2 \%$ & 79.50 & 79.83 & 6.72 & 6.99 & 13.16 & 13.50 \\
\hline & $0.4 \%$ & 83.00 & 83.33 & 6.39 & 6.63 & 12.33 & 12.16 \\
\hline \multicolumn{2}{|l|}{ Mean } & 81.66 & 81.99 & 6.47 & 6.73 & 12.37 & 12.49 \\
\hline \multirow{4}{*}{$60 \%$} & $0.0 \%$ & 76.50 & 76.83 & 7.47 & 7.72 & 12.16 & 12.16 \\
\hline & $0.1 \%$ & 73.50 & 73.83 & 7.73 & 7.99 & 13.00 & 13.33 \\
\hline & $0.2 \%$ & 72.00 & 72.33 & 7.94 & 8.14 & 13.66 & 14.00 \\
\hline & $0.4 \%$ & 75.83 & 76.16 & 7.58 & 7.92 & 12.83 & 13.16 \\
\hline \multicolumn{2}{|l|}{ Mean } & 74.45 & $\mathbf{7 4 . 7 8}$ & 7.68 & 7.94 & 12.91 & 13.16 \\
\hline \multirow{4}{*}{$80 \%$} & $0.0 \%$ & 67.50 & 67.83 & 7.82 & 8.08 & 12.83 & 12.16 \\
\hline & $0.1 \%$ & 65.50 & 65.83 & 8.18 & 8.35 & 14.00 & 14.16 \\
\hline & $0.2 \%$ & 65.16 & 65.50 & 8.29 & 8.50 & 14.33 & 14.66 \\
\hline & $0.4 \%$ & 67.50 & 67.83 & 7.94 & 8.13 & 13.16 & 13.33 \\
\hline \multicolumn{2}{|l|}{ Mean } & 66.41 & 66.74 & 8.05 & 8.26 & 13.58 & 13.57 \\
\hline \multirow{4}{*}{$100 \%$} & $0.0 \%$ & 66.66 & 67.00 & 9.29 & 9.38 & 13.16 & 13.16 \\
\hline & $0.1 \%$ & 64.16 & 64.50 & 9.52 & 9.71 & 14.66 & 15.00 \\
\hline & $0.2 \%$ & 64.00 & 64.33 & 9.63 & 9.87 & 15.16 & 15.33 \\
\hline & $0.4 \%$ & 66.66 & 67.00 & 9.38 & 9.55 & 14.00 & 14.00 \\
\hline \multicolumn{2}{|l|}{ Mean } & 65.37 & 65.70 & 9.45 & 9.62 & 14.24 & 14.37 \\
\hline \multirow{4}{*}{ Mean (PAM) } & $0.0 \%$ & 76.53 & 76.86 & 7.40 & 7.60 & 12.16 & 11.96 \\
\hline & $0.1 \%$ & 74.13 & 74.46 & 7.66 & 7.87 & 13.29 & 13.63 \\
\hline & $0.2 \%$ & 73.29 & 73.63 & 7.80 & 8.03 & 13.82 & 14.09 \\
\hline & $0.4 \%$ & 76.19 & 76.53 & 7.48 & 7.72 & 12.79 & 12.89 \\
\hline \multirow{3}{*}{ L.S.D. at 0.05} & F.C. & 1.36 & 1.27 & 0.09 & 0.08 & 0.39 & 0.39 \\
\hline & PAM & 0.35 & 0.32 & 0.03 & 0.05 & 0.23 & 0.24 \\
\hline & F.C. $\times$ PAM & 1.52 & 1.42 & 0.10 & 0.13 & 0.59 & 0.12 \\
\hline
\end{tabular}


the lowest level. These results may be due to using a suitable level of the available moisture which activates the root system to grow early on the planted corms and sprout early and absorbs an adequate amount of the nutrients needed for the biosynthesis process, which led to produce and accumulate the flowering materials that accelerate the initiation and formation of the flowers. As a result, the time needed for showing color stage could be decreased. Similar trend was found by Mostafa and Asker (1997) with Dianthus barbatus and Senecio cruentus.

In addition, the data presented in Table (4-a) showed that the addition of polyacrylamide at $0.2 \%$ gave the shortest time taken to showing color in both seasons, compared with the other rates. These results may be due to the influence of the added polyacrylamide at a suitable ratio on increasing the efficiency of the soil water and fertilizer. Consequently, the plants reach showing color stage early. Similar trend was found by Mostafa et al. (1997) on Chrysanthemum.

Generally, the data on the flower diameter showed that the maximum floret diameter per spike was found at the highest level of the available moisture of the sandy soil combined with $0.2 \%$ polyacrylamide in both seasons, 9.63 and $9.87 \mathrm{~cm}$, respectively (Table (4-a). These results may be related to the effect of polyacrylamide at a suitable concentration on improving the physical properties of the sandy soil, especially when the soil contains the suitable amount of water, consequently the plants could produce good spikes with many florets. Similar trend was found by Devitt et al. (1991) on Catharanthus roseus.

Generally, the data of the two seasons in Table (4-a) indicated that using the highest level of the available moisture (100\% of field capacity) gave the longest significant flowering duration of gladiolus flowers (15.16 and 15.33 days,) respectively, as compared with all the other treatments. The previous results may be due to using a suitable amount of the available moisture in the sandy soil which led to increase the absorption of the necessary nutrient elements for growth. Thus the growth rate of gladiolus plants could be increased, consequently producing vigorous plants with a long spike with more flowers, and as a result the period of the flowering duration could be increased. Similar trend was reported by Mostafa and Asker (1997) with Dianthus barbatus and Senecio cruentus.
Generally, the data on the number of florets per spike showed that the maximum number was found at the highest level of the available moisture of the sandy soil combined with $0.2 \%$ polyacrylamide in both seasons (Table 4-b). These results may be related to the effect of polyacrylamide at a suitable concentration on improving the physical properties of the sandy soil, especially when the soil contains the suitable amount of water, consequently the plants could produce good spikes with many flowers. Similar trend was found by Devitt et al. (1991) with Catharanthus roseus.

Also, the means of rachis length per plant in the two seasons in Table (4-b) indicated that reducing the level of the available moisture of the sandy soil less than $100 \%$ of field capacity decreased the rachis length per plant. The shortest rachis length per plant was found by using $20 \%$ of the available moisture of the soil, which was 36.91 and $37.25 \mathrm{~cm}$ using $0.4 \%$ PAM in both seasons, respectively. While the highest rachis length was 49.25 and $50.08 \mathrm{~cm}$ using $0.2 \%$ PAM in both seasons, respectively. These results were probably due to the role of water at a suitable level in plant, which is necessary for nutrient element absorption, chemical combinations that result in the formation of plant food, as a medium through which food and nutrient elements are moved from cell to cell, and to fill the vacuoles in the cells necessary to keep the tissues turgid. As a result, the size of the cells and the division rate of the apical meristem could be increased, consequently the spike length will increase. Similar trend was reported by Mousa and El-Keltawi (1983) with Strelitzia reginae.

The data of both seasons in Table (4-b) showed that the longest rachis per flowering spike was obtained by adding the highest level of the available water (100\% of field capacity) combined with polyacrylamide at $0.2 \%$. These results may be related to the effect of polyacrylamide at a suitable rate on improving the physical properties of the sandy soil especially when the soil contains enough amount of the available moisture, accordingly the plants could absorb the needed water and nutrient elements for improving the whole growth of the plants. As a result, the length of the rachis will increase. Similar trend was reported by Devitt $e t$ al. (1991) with Catharanthus roseus and Mostafa and Asker (1997) with Dianthus barbatus and Senecio cruentus. 
Table (4-b): Means of flowering characteristics of Gladiolus hybrida cv. White Prosperity plants as influenced by field capacity percentage (F.C.), polyacrylamide (PAM) percentage $(\%)$ and their combinations (F.C. $\times$ PAM) in the two seasons of $(2012 / 2013)$ and $(2013 / 2014)$.

\begin{tabular}{|c|c|c|c|c|c|c|c|}
\hline \multicolumn{2}{|c|}{ Treatments } & \multicolumn{2}{|c|}{$\begin{array}{c}\text { Florets } \\
\text { number per } \\
\text { spike }\end{array}$} & \multicolumn{2}{|c|}{$\begin{array}{l}\text { Rachis length } \\
\text { (cm) }\end{array}$} & \multicolumn{2}{|c|}{$\begin{array}{c}\text { Florets dry } \\
\text { weight (g) }\end{array}$} \\
\hline $\begin{array}{c}\text { Field } \\
\text { capacity }(\%)\end{array}$ & $\begin{array}{c}\text { Polyacrylamide } \\
(\%)\end{array}$ & $\begin{array}{l}2012 \\
/ 2013\end{array}$ & $\begin{array}{l}2013 \\
/ 2014\end{array}$ & $\begin{array}{l}2012 \\
/ 2013\end{array}$ & $\begin{array}{l}2013 \\
/ 2014\end{array}$ & $\begin{array}{l}2012 \\
/ 2013\end{array}$ & \begin{tabular}{|l|}
2013 \\
$/ 2014$
\end{tabular} \\
\hline \multirow{4}{*}{$20 \%$} & $0.0 \%$ & 8.50 & 9.16 & 37.00 & 37.41 & 0.84 & 0.85 \\
\hline & $0.1 \%$ & 8.83 & 8.66 & 38.08 & 38.58 & 0.90 & 0.92 \\
\hline & $0.2 \%$ & 9.66 & 9.83 & 38.83 & 39.50 & 0.94 & 0.96 \\
\hline & $0.4 \%$ & 9.00 & 9.50 & 36.91 & 37.25 & 0.84 & 0.87 \\
\hline \multicolumn{2}{|l|}{ Mean } & 8.99 & 9.28 & 37.70 & 38.18 & 0.88 & \begin{tabular}{|l|}
0.90 \\
\end{tabular} \\
\hline \multirow{4}{*}{$40 \%$} & $0.0 \%$ & 8.83 & 8.33 & 37.91 & 38.41 & 1.89 & 1.90 \\
\hline & $0.1 \%$ & 9.16 & 9.33 & 38.75 & 39.16 & 1.93 & 1.97 \\
\hline & $0.2 \%$ & 10.33 & 10.50 & 41.58 & 42.33 & 2.08 & 2.11 \\
\hline & $0.4 \%$ & 8.66 & 9.33 & 39.41 & 39.16 & 1.94 & \begin{tabular}{|l|}
1.95 \\
\end{tabular} \\
\hline \multicolumn{2}{|l|}{ Mean } & 9.24 & 9.37 & 39.41 & 39.76 & 1.96 & 1.98 \\
\hline \multirow{4}{*}{$60 \%$} & $0.0 \%$ & 9.83 & 9.33 & 38.91 & 39.58 & 1.94 & \begin{tabular}{|l|}
1.97 \\
\end{tabular} \\
\hline & $0.1 \%$ & 11.16 & 11.33 & 40.58 & 41.00 & 2.04 & 2.05 \\
\hline & $0.2 \%$ & 12.33 & 12.50 & 42.41 & 43.33 & 2.11 & 2.16 \\
\hline & $0.4 \%$ & 10.66 & 11.33 & 40.33 & 41.16 & 2.01 & 2.05 \\
\hline \multicolumn{2}{|l|}{ Mean } & 10.99 & 11.12 & 40.55 & 41.26 & 2.02 & 2.05 \\
\hline \multirow{4}{*}{$80 \%$} & $0.0 \%$ & 11.83 & 11.33 & 41.75 & 42.00 & 2.08 & 2.09 \\
\hline & $0.1 \%$ & 13.16 & 13.33 & 45.41 & 45.58 & 2.25 & 2.24 \\
\hline & $0.2 \%$ & 14.16 & 14.16 & 46.08 & 46.08 & 2.31 & 2.29 \\
\hline & $0.4 \%$ & 12.33 & 12.83 & 44.00 & 43.50 & 2.20 & 2.17 \\
\hline \multicolumn{2}{|l|}{ Mean } & 12.87 & 12.91 & 44.31 & 44.29 & 2.21 & 2.19 \\
\hline \multirow{4}{*}{$100 \%$} & $0.0 \%$ & 12.66 & 12.16 & 44.66 & 45.41 & 2.23 & 2.24 \\
\hline & $0.1 \%$ & 14.16 & 14.33 & 46.41 & 46.91 & 2.31 & 2.33 \\
\hline & $0.2 \%$ & 15.33 & 15.50 & 49.25 & 50.08 & 2.47 & 2.50 \\
\hline & $0.4 \%$ & 13.33 & 13.83 & 45.58 & 45.41 & 2.28 & 2.27 \\
\hline \multicolumn{2}{|l|}{ Mean } & 13.87 & 13.95 & 46.47 & 46.95 & 2.32 & 2.33 \\
\hline \multirow{4}{*}{ Mean (PAM) } & $0.0 \%$ & 10.33 & 10.06 & 40.04 & 40.56 & 1.79 & 1.81 \\
\hline & $0.1 \%$ & 11.30 & 11.40 & 41.84 & 42.24 & 1.88 & 1.90 \\
\hline & $0.2 \%$ & 12.36 & 12.50 & 43.63 & 44.26 & 1.98 & 2.00 \\
\hline & $0.4 \%$ & 10.80 & 11.36 & 41.24 & 41.29 & 1.85 & 1.86 \\
\hline \multirow{3}{*}{ L.S.D. at 0.05} & F.C. & 0.65 & 0.36 & 0.54 & 0.38 & 0.03 & 0.02 \\
\hline & PAM & 0.29 & 0.34 & 0.33 & 0.35 & 0.01 & 0.01 \\
\hline & F.C. $\times$ PAM & 0.86 & 0.74 & 0.84 & 0.76 & 0.03 & 0.04 \\
\hline
\end{tabular}

The same trend was found in floret dry weight. It was found that using $100 \%$ of water field capacity in combination of $0.2 \%$ PAM gave the highest dry weight $(2.47$ and $2.50 \mathrm{~g})$ in the two seasons, respectively.

Generally, the average of the florets number per spike at $100 \%$ field capacity and $0.2 \%$ PAM was 15.33 and 15.50 in the first and second seasons, respectively. The extent of any fall in the first grade (Class I) of export (which is how far along florets number greater than 9 florets), GOEIC (1988). We found that the increase of the floret number per spike at $80 \%$ field capacity and $0.2 \%$ PAM was 14.16 in the both seasons. The extent of any fall in the first grade (Class I) for export (which is how far along florets number between 8-9 florets), GOEIC (1988).

\subsection{Corm production}

Generally, the data of the two seasons in Table (5) showed that the largest corm diameter was 5.02 and $5.28 \mathrm{~cm}$ in the first and second seasons, respectively. The corm dry weight was 3.19 and $3.34 \mathrm{~g}$, respectively, and the highest number of the new cormlets per plant were (17.16 and 17.83 cormlets) found by adding the highest level of water content (100\% of field capacity) combined with polyacrylamide at 0.2 
Table (5): Means of corm production of Gladiolus hybrida cv. White Prosperity plants as influenced by field capacity percentage (F.C.), polyacrylamide (PAM) percentage $(\%)$ and their combinations (F.C. $\times$ PAM) in the two seasons of (2012/2013) and (2013/2014).

\begin{tabular}{|c|c|c|c|c|c|c|c|}
\hline \multicolumn{2}{|c|}{ Treatments } & \multicolumn{2}{|c|}{$\begin{array}{l}\text { Corm diameter } \\
(\mathbf{c m})\end{array}$} & \multicolumn{2}{|c|}{$\begin{array}{l}\text { Corm dry } \\
\text { weight }(g)\end{array}$} & \multicolumn{2}{|c|}{$\begin{array}{c}\text { Cormlet } \\
\text { number per } \\
\text { plant }\end{array}$} \\
\hline $\begin{array}{c}\text { Field } \\
\text { capacity }(\%)\end{array}$ & $\begin{array}{c}\text { Polyacrylamide } \\
(\%)\end{array}$ & $\begin{array}{l}2012 \\
/ 2013\end{array}$ & $\begin{array}{c}2013 \\
/ 2014\end{array}$ & $\begin{array}{l}2012 \\
/ 2013\end{array}$ & $\begin{array}{l}2013 \\
/ 2014\end{array}$ & $\begin{array}{l}2012 \\
/ 2013\end{array}$ & $\begin{array}{l}2013 \\
/ 2014\end{array}$ \\
\hline \multirow{4}{*}{$20 \%$} & $0.0 \%$ & 2.85 & 2.99 & 1.67 & 1.84 & 9.83 & 10.16 \\
\hline & $0.1 \%$ & 3.23 & 3.34 & 1.98 & 2.11 & 11.00 & 11.33 \\
\hline & $0.2 \%$ & 3.74 & 3.71 & 2.22 & 2.38 & 12.16 & 12.50 \\
\hline & $0.4 \%$ & 2.83 & 3.05 & 1.74 & 1.90 & 9.66 & 10.16 \\
\hline \multicolumn{2}{|l|}{ Mean } & 3.16 & 3.27 & 1.90 & 2.05 & 10.66 & 11.03 \\
\hline \multirow{4}{*}{$40 \%$} & $0.0 \%$ & 3.03 & 3.20 & 1.83 & 2.02 & 10.33 & 10.83 \\
\hline & $0.1 \%$ & 3.99 & 4.14 & 2.41 & 2.60 & 13.33 & 13.83 \\
\hline & $0.2 \%$ & 4.22 & 4.44 & 2.58 & 2.80 & 14.33 & 14.83 \\
\hline & $0.4 \%$ & 3.25 & 3.58 & 2.00 & 2.24 & 11.00 & 12.00 \\
\hline \multicolumn{2}{|l|}{ Mean } & 3.62 & 3.84 & 2.20 & 2.41 & 12.24 & 12.87 \\
\hline \multirow{4}{*}{$60 \%$} & $0.0 \%$ & 3.20 & 3.58 & 1.98 & 2.26 & 11.00 & 12.00 \\
\hline & $0.1 \%$ & 3.80 & 4.11 & 2.35 & 2.59 & 13.00 & 13.66 \\
\hline & $0.2 \%$ & 4.42 & 4.64 & 2.71 & 2.88 & 15.00 & 15.66 \\
\hline & $0.4 \%$ & 3.30 & 3.54 & 1.98 & 2.25 & 11.00 & 11.66 \\
\hline \multicolumn{2}{|l|}{ Mean } & 3.68 & 3.96 & 2.25 & 2.49 & 12.50 & 13.24 \\
\hline \multirow{4}{*}{$80 \%$} & $0.0 \%$ & 3.55 & 3.75 & 2.15 & 2.32 & 12.16 & 12.50 \\
\hline & $0.1 \%$ & 4.31 & 4.54 & 2.64 & 2.87 & 14.66 & 15.33 \\
\hline & $0.2 \%$ & 4.83 & 5.05 & 2.98 & 3.18 & 16.50 & 17.00 \\
\hline & $0.4 \%$ & 3.73 & 4.02 & 2.29 & 2.53 & 12.66 & 13.33 \\
\hline \multicolumn{2}{|l|}{ Mean } & 4.10 & 4.34 & 2.51 & 2.72 & 13.99 & 14.54 \\
\hline \multirow{4}{*}{$100 \%$} & $0.0 \%$ & 3.56 & 3.81 & 2.16 & 2.35 & 12.16 & 12.83 \\
\hline & $0.1 \%$ & 4.36 & 4.54 & 2.65 & 2.87 & 14.66 & 15.33 \\
\hline & $0.2 \%$ & 5.02 & 5.28 & 3.19 & 3.34 & 17.16 & 17.83 \\
\hline & $0.4 \%$ & 3.78 & 4.03 & 2.36 & 2.52 & 12.83 & 13.33 \\
\hline \multicolumn{2}{|l|}{ Mean } & 4.18 & 4.41 & 2.59 & 2.77 & 14.20 & 14.83 \\
\hline \multirow{4}{*}{$\begin{array}{l}\text { Mean } \\
\text { (PAM) }\end{array}$} & $0.0 \%$ & 3.23 & 3.46 & 1.95 & 2.15 & 11.09 & 11.66 \\
\hline & $0.1 \%$ & 3.93 & 4.13 & 2.40 & 2.60 & 13.33 & 13.89 \\
\hline & $0.2 \%$ & 4.44 & 4.62 & 2.73 & 2.91 & 15.03 & 15.56 \\
\hline & $0.4 \%$ & 3.37 & 3.64 & 2.07 & 2.28 & 11.43 & 12.09 \\
\hline \multirow{3}{*}{$\begin{array}{l}\text { L.S.D. at } \\
0.05\end{array}$} & F.C. & 0.18 & 0.25 & 0.08 & 0.14 & 0.48 & 0.70 \\
\hline & PAM & 0.08 & 0.09 & 0.03 & 0.05 & 0.19 & 0.28 \\
\hline & F.C. $\times$ PAM & 2.05 & 2.27 & 1.35 & 1.42 & 7.19 & 7.56 \\
\hline
\end{tabular}

$\%$. These results may be due to the role of polyacrylamide at a suitable concentration, on improving the physical properties of the sandy soil, especially when the soil contains the proper level of the available moisture, consequently producing vigorous plants, and accordingly resulted in more back translocation and accumulation of organic matter, which led to the production of large and many cormes per plant. Similar results were found by El-Naggar and Nassar (1994) with Narcissus tazetta and AlHumaid and Al-Moftah (2005) with Polianthes tuberosa.

\subsection{Chemical constituents}

The data of the two seasons (Table 6) showed that the maximum total chlorophyll content of gladiolus leaves was found by using the highest level of the available moisture $(100 \%$ of field capacity) combined with polyacrylamide at 0.2 $\%$, which was 1.34 and $1.32 \mathrm{mg} / \mathrm{g}$ fresh weight, respectively, compared with the other treatments. These results were probably due to using a suitable level of available moisture that led to increasing the absorption of water and nutrient elements, especially nitrogen and magnesium needed for chlorophyll formation. In addition to the presence of polyacrylamide at a 
proper concentration increases the availability of nitrogen and leaf water potential, thus, the synthesis of the green pigment could be increased. Similar results were obtained by AlMoftah and Al-Humaid (2004) with Polianthes tuberosa.

Furthermore, the data of the Table (6) showed that using the lowest level of the available moisture (20\% of field capacity) combined with polyacrylamide at $0.4 \%$ gave the highest value of proline in gladiolus leaves,
(2.52 and $2.65 \mathrm{mg} / \mathrm{g}$ ), for both seasons respectively, as compared with the other treatments. This result was probably due to the fact that protein formation requires a suitable level of water inside the plant tissues, consequently the free amino acids especially proline could be increased in the gladiolus leaves. Similar results were found by Khalil (2003), Kim et al. (2004) and Kohler et al. (2008) on other plants.

Also, the data of the Table (6) cleared that the

Table (6): Means of chemical constituents of Gladiolus hybrida cv. White Prosperity plants as influenced by field capacity percentage (F.C.), polyacrylamide (PAM) percentage (\%) and their combinations (F.C. $\times$ PAM) in the two seasons of (2012/2013) and (2013/2014).

\begin{tabular}{|c|c|c|c|c|c|c|c|}
\hline \multicolumn{2}{|c|}{ Treatments } & \multicolumn{2}{|c|}{$\begin{array}{l}\text { Total chlorophyll } \\
\text { content (mg/ g } \\
\text { fresh weight ) }\end{array}$} & \multicolumn{2}{|c|}{$\begin{array}{l}\text { Proline content } \\
\quad(\mathrm{mg} / \mathrm{g})\end{array}$} & \multicolumn{2}{|c|}{$\begin{array}{c}\text { Total } \\
\text { carbohydrates } \\
\text { content } \\
\text { New corms } \\
(\%)\end{array}$} \\
\hline $\begin{array}{c}\text { Field } \\
\text { capacity }\end{array}$ & Polyacrylamide (\%) & $\begin{array}{l}2012 \\
/ 2013\end{array}$ & $\begin{array}{l}2013 \\
/ 2014\end{array}$ & $\begin{array}{l}2012 \\
/ 2013\end{array}$ & $\begin{array}{r}2013 \\
/ 2014\end{array}$ & $\begin{array}{r}2012 \\
/ 2013\end{array}$ & $\begin{array}{r}2013 \\
/ 2014\end{array}$ \\
\hline \multirow{4}{*}{$20 \%$} & $0.0 \%$ & 0.87 & 0.85 & 2.51 & 2.64 & 32.06 & 33.24 \\
\hline & $0.1 \%$ & 0.94 & 0.92 & 2.44 & 2.56 & 35.70 & 36.30 \\
\hline & $0.2 \%$ & 1.00 & 0.98 & 2.45 & 2.57 & 37.30 & 37.63 \\
\hline & $0.4 \%$ & 0.92 & 0.90 & 2.52 & 2.65 & 32.75 & 33.89 \\
\hline \multicolumn{2}{|l|}{ Mean } & 0.93 & 0.91 & 2.48 & 2.60 & 34.45 & 35.26 \\
\hline \multirow{4}{*}{$40 \%$} & $0.0 \%$ & 0.90 & 0.88 & 2.34 & 2.46 & 43.09 & 44.15 \\
\hline & $0.1 \%$ & 0.97 & 0.95 & 2.26 & 2.38 & 46.28 & 47.79 \\
\hline & $0.2 \%$ & 1.02 & 1.00 & 2.25 & 2.37 & 47.43 & 49.03 \\
\hline & $0.4 \%$ & 0.92 & 0.91 & 2.36 & 2.48 & 44.25 & 45.73 \\
\hline \multicolumn{2}{|l|}{ Mean } & 0.95 & 0.93 & 2.30 & 2.42 & 45.26 & 46.67 \\
\hline \multirow{4}{*}{$60 \%$} & $0.0 \%$ & 0.98 & 0.96 & 1.93 & 2.03 & 53.04 & 53.75 \\
\hline & $0.1 \%$ & 1.05 & 1.03 & 1.86 & 1.95 & 55.56 & 56.39 \\
\hline & $0.2 \%$ & 1.09 & 1.06 & 1.83 & 1.93 & 57.55 & 57.84 \\
\hline & $0.4 \%$ & 1.01 & 0.99 & 1.96 & 2.06 & 53.24 & 53.29 \\
\hline \multicolumn{2}{|l|}{ Mean } & 1.03 & 1.01 & 1.89 & 1.99 & 54.84 & 55.31 \\
\hline \multirow{4}{*}{$80 \%$} & $0.0 \%$ & 1.11 & 1.09 & 1.62 & 1.70 & 62.17 & 64.26 \\
\hline & $0.1 \%$ & 1.26 & 1.24 & 1.55 & 1.63 & 65.14 & 67.00 \\
\hline & $0.2 \%$ & 1.29 & 1.27 & 1.56 & 1.64 & 66.20 & 68.45 \\
\hline & $0.4 \%$ & 1.17 & 1.15 & 1.64 & 1.72 & 63.73 & 65.24 \\
\hline \multicolumn{2}{|l|}{ Mean } & 1.20 & 1.18 & 1.59 & 1.67 & 64.31 & 66.23 \\
\hline \multirow{4}{*}{$100 \%$} & $0.0 \%$ & 1.23 & 1.21 & 1.34 & 1.41 & 72.37 & 74.82 \\
\hline & $0.1 \%$ & 1.31 & 1.29 & 1.24 & 1.31 & 74.33 & 76.84 \\
\hline & $0.2 \%$ & 1.34 & 1.32 & 1.25 & 1.31 & 76.19 & 78.45 \\
\hline & $0.4 \%$ & 1.26 & 1.24 & 1.33 & 1.40 & 71.45 & 73.86 \\
\hline \multicolumn{2}{|l|}{ Mean } & 1.28 & 1.26 & 1.29 & 1.35 & 73.58 & 75.99 \\
\hline \multirow{4}{*}{$\begin{array}{l}\text { Mean } \\
\text { (PAM) }\end{array}$} & $0.0 \%$ & 1.01 & 0.99 & 1.94 & 2.04 & 52.54 & 54.04 \\
\hline & $0.1 \%$ & 1.10 & 1.08 & 1.87 & 1.96 & 55.40 & 56.86 \\
\hline & $0.2 \%$ & 1.14 & 1.12 & 1.86 & 1.96 & 56.93 & 58.28 \\
\hline & $0.4 \%$ & 1.05 & 1.03 & 1.96 & 2.06 & 53.08 & 54.39 \\
\hline \multirow{3}{*}{$\begin{array}{l}\text { L.S.D. at } \\
0.05\end{array}$} & F.C. & 0.01 & 0.01 & 0.01 & 0.01 & 2.10 & 3.09 \\
\hline & PAM & 0.01 & 0.01 & 0.01 & 0.01 & 0.55 & 0.51 \\
\hline & F.C. $\times$ PAM & 0.01 & 0.16 & 0.02 & 0.02 & 3.50 & 3.24 \\
\hline
\end{tabular}


highest rate of carbohydrate content (76.19 and $78.45 \%$ ) of the new gladiolus corms was found by adding the highest level of the available moisture (100\% of field capacity) combined with polyacrylamide at $0.2 \%$, for both seasons respectively respectively. This result may be related to the effect of polyacrylamide at a proper concentration on improving the physical properties of the sandy soil and decreased the leached amount of organic and inorganic solutes, especially when the soil contains the suitable amount of the available moisture. Consequently producing vigorous plants with many large leaves, and as a result, a large amount of carbohydrates could be formed and translocated to the new corms.

\section{REFERENCES}

AI-Harbi A., AI-Omran A., Shalaby A. and Choudharyv M. (1999). Efficacy of hydrophilic polymer declines with time in greenhouse experiments. Hort. Sci. Abst., 34: $223-224$.

Al-Humaid A. and Al-Moftah A. (2005). Response of vegetative and reproductive parameters of water stressed tuberose (Polianthes tuberosa L.) plants to Vapor Gard and Kaolin antitranspirants. J. Appl. Hort. Lucknow, 7(2): $72-78$.

Al-Moftah A. and Al-Humaid A. (2004). Effect of kaolin and pinolene film-forming polymers on water relations and photosynthetic rate of tuberose (Polianthes tuberosa, L.) plants under water deficit conditions. J. Appl. Hort., 6 (2): $16-22$.

Bates L., Waldern R. and Teare I. (1973). Rapid determination of free proline for water stress studies. Plant and Soil, 39: $205-207$.

Clarence J.H. (1945). World of plant life, the Iris (Iridaceae) family. First edition, The MaCmillan Publishing Company, New York, U.S.A. pp 572-574.

Devitt D., Morris R. and Bowman D. (1991). Response of periwinkle to sewage sludge used as a soil amendement. J. Environ. Hort., 9: $176-181$.

Dubios M., Gilles K., Hamlton J., Rebers P. and Smith F. (1956). Colourimetric method for determination of sugars and related substances, Analy. Chem., 28 (3): 350- 356.

El-Naggar A. and Nassar I. (1994). Performance of Narcissus tazetta, L. as influenced by soil water matric potential (SWMP) under different soil textures. Assiut J. Agric. Sci., 25(1): 149 - 170.

General Organization for Export and Import Control (GOEIC) (1988). Quality specifications of medicinal plants and aromatic oils and flowers exported. Ministry of Trade, Industry and Investment. p.51-53.

Halepyati A., Sujatha K. and Prabhakar M. (2002). Growth, yield and water use of summer tuberose as influenced by irrigation regime and plant densities. J. Orna. Hort. New Series, 5 (1): 47 - 50.

Jackson N. L. (1958). Soil Chemical Analysis. Constable. Ltd. Co., London, U.K., 498 p.

Johnson M.S. (1984). Effects of gel-forming polyacrylamides on moisture storage in sandy soils. J. Sci. Food Agric., 35: 11961200.

Khalil H. (2003). Effect of water stress and the soil conditioner, PAM, on growth and chemical composition of young Valencia orange and Manzanillo Olive trees. M.sc. Thesis, Fac. Agric., Alex. Univ., Alex., Egypt.

Khattab M., El-Shennawy O., Mostafa M. and Gomaa N. (2002). Effect of some soil conditioners and irrigation rates on the growth and flowering of Salvia splendens plants. Alex. J. Agric. Res., 47(2): 163 172.

Kim T., Bok-Rye L., Jung W., Kim K., Avice J. and Ourry A. (2004). De novo protein synthesis in relation to ammonia and proline accumulation in water stressed white clover. Functional Plant Biology, 31(8) 847-855.

Klock-Moore K. (2000). Comparison of Salvia growth in seaweed compost and biosolids compost. Compost Science and Utilization, 8: $24-28$.

Kohler J., Hernández J., Caravaca F. and Roldán A. (2008). Plant-growthpromoting Rhizobacteria and Arbuscular Mycorrhizal fungi modify alleviation biochemical mechanisms in water-stressed plants. Functional Plant Biology, 35(2): $141-151$.

Lewis G.J., Obermeryer A.A. and Bernard T.T. (1972). Gladiolus, A revision of the South African species. Journal of South African Botany, Vol. 10 (Supplementary).

Matt M. and Muhar A. (1990). Germination, growth and elements uptake of turf 
grasses on substrates with high levels os sewage sludge. Soil and Fert. Abst., 53:11436.

Misra A. and Srivastava N. (2000). Influence of water stress on Japanese mint. J. Herb. Spic. \& Medic. Plants, 7(1): $51-58$.

Mohamed A. (2002). Effect of irrigation and fertilization on Pelargonium graveolens, L. and Rosmarinus officinalis, L. under Sinai conditions. Ph. D. Thesis, Fac. Agric., Kafr El-Sheikh, Tanta Univ., Egypt, pp: 156.

Moran R. and Porath D. (1980). Chlorophyll determination in intact tissues using N,NDimethylformamide. Department of Botany, The George. S. Wise Faculty for life sciences, Tel Aviv University, Ramat Aviv, Israel. Plant Physiol., 65: 478- 479.

Mostafa M. (2002). Effect of polyacrylamide, sewage sludge compost and irrigation frequency on the growth of Dendranthema grandiflorum, Ramat plant. Alex. J. Agric. Res., 47(3): 109 120.

Mostafa M. and Asker F. (1997). Effect of soil conditioners on the growth of Dianthus barbatus and Senecio cruentus plants. J. Agric. Sci. Mansoura Univ., 22: 11551167.
Mostafa M., El-Haddad E. and Amer M. (1997). Effectiveness of foliar nutrition with some micro-elements of chrysanthemum plant. Alex. J. Agric. Res., 42: $81-93$.

Mousa G. and El-Keltawi N. (1983). Response of Strelitzia reginae, Banks to different soil water regimes. Assiut j. Agric. Sci., 14 (2): 193 - 204.

Sivapalan S. (2006). Benefits of treating a sandy soil with a crosslinked type polyacrylamide. Australian J. Exper. Agric., 46 (4): 579 - 584.

Snedecor G. and Cochran W. (1974). Statistical Methods. Sixth Edition. Iowa State University Press. Ames. Iowa. USA.

Tripepi R., George M., Dumoese R. and Wenny D. (1991). Birch seedling response to irrigation frequency and a hydrophilic polymer amendment in a container medium. J. Environ. Hort., 9: $119-123$.

Yadav L. P. and Maity R. (1989). Gladiolus C.f. Commercial Flowers. Bose T. K. and Yadav, L.P. (eds) Naya Prokash, Calutta, India.

$$
\begin{aligned}
& \text { تأثير الري والبولي أكريلميد على إنتاج نباتات الجلاديولس في الأراضي الرملية } \\
& \text { *نادر أحمد الثنهورى-رحاب أحمد صفار } \\
& \text { فرع بحوث الحدائق النباتية و * فرع بحوث نباتات الزينة بأنطونيادس - معهد بحوث البساتين- } \\
& \text { مركز البحوث الزر اعية ـ الاسكندرية ـ مصر بـانية }
\end{aligned}
$$

أجرى هذا البحث فى مزر عة البحوث بأنطونيادس - معهد بحوث البساتين بالإسكندرية خلانل عـامي 2014/2013 مل و

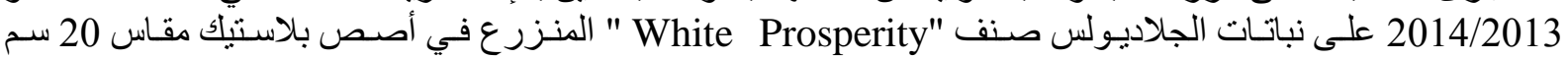

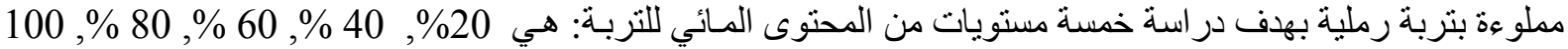

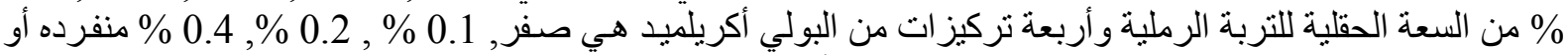

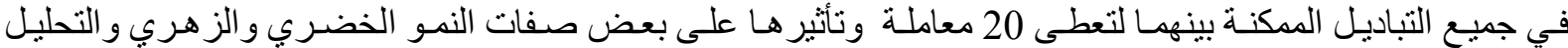
الكيماوي لنباتات الجلاديولس النامية في التربة الرئية الرملية.

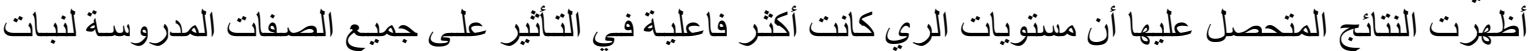
الجلاديولس بمقارنتها بتركيز ات البولي أكريلمبد. و عموما أعطي استخدام أعلى مستوى من الرطوبـة الأرضية ( 100 \%

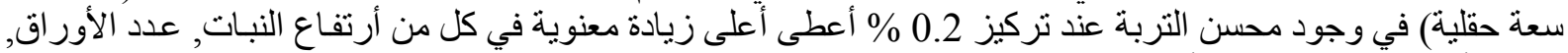

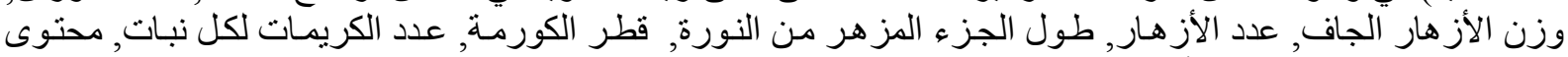

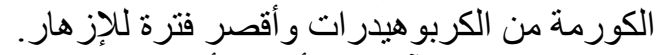

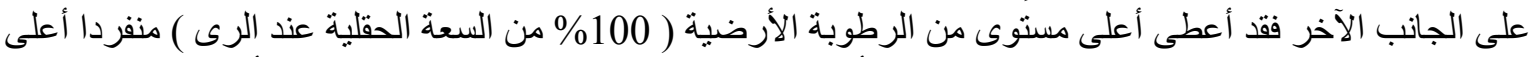

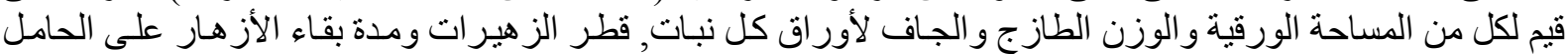
الزهري, وزن الأزهار الجاف, محتوى الأوراق من الكلوروفيل الكلى وأقل محتوى من التورن البرولين. 


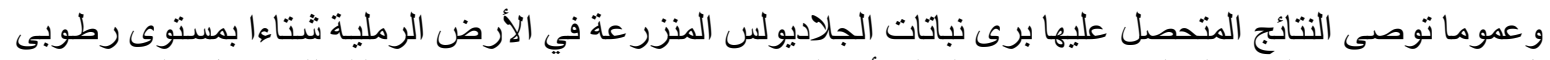

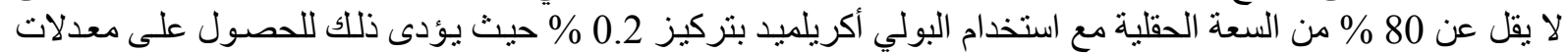

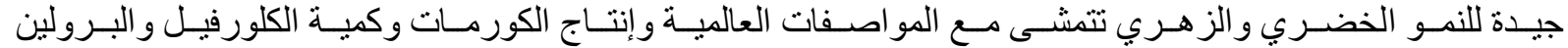

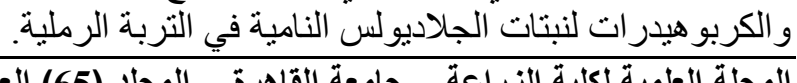

المجلة العلمية لكلية الزراعة - جامعة القاهرة - المجلد (65) العدد الثالثة (يوليو التربة 2014):283-294. 